Revue musicale OICRM

\title{
Keeping Choro Alive in Brazilian Concert Music for Bassoon
}

\section{Ariana Pedrosa}

Volume 6, numéro 1, 2019

Documenter, analyser et révéler la création sonore en interprétation musicale

URI : https://id.erudit.org/iderudit/1062427ar

DOI : https://doi.org/10.7202/1062427ar

Aller au sommaire du numéro

\section{Éditeur(s)}

Observatoire interdisciplinaire de création et recherche en musique (OICRM)

ISSN

2368-7061 (numérique)

Découvrir la revue

Citer cet article

Pedrosa, A. (2019). Keeping Choro Alive in Brazilian Concert Music for Bassoon. Revue musicale OICRM, 6(1), 37-47. https://doi.org/10.7202/1062427ar

\section{Résumé de l'article}

La musique de concert brésilienne pour le basson, fruit du mouvement nationaliste des $\mathrm{XIX}^{\mathrm{e}}$ et $\mathrm{XX}{ }^{\mathrm{e}}$ siècles, apporte un défi aux interprètes étant donné les circonstances dans lesquelles ce répertoire émergea ainsi que les influences qui lui sont particulières. Ici, le rôle et l'influence que la musique populaire brésilienne a eu dans la formation de ce répertoire est souvent méconnu ou sous-estimé. Un genre important de la musique populaire brésilienne, unique à cette nation, est le choro. Il est impossible de proposer une interprétation fidèle, authentique, des nombreuses oeuvres nationalistes brésiliennes, oeuvres grandement influencées par le choro, sans avoir préalablement une certaine connaissance et un contact avec ce genre. Ces considérations deviennent particulièrement pertinentes en raison de la grande popularité dans le monde entier du répertoire de musique de concert brésilien pour le basson. La pratique de performance « de bon goût " peut, notamment, renforcer les lacunes dans les connaissance par le rapprochement des liens manquants, fournissant des informations et références de base suffisantes et claires, afin de sensibiliser aux pratiques et aux conventions de l'époque et du style, transmettant le savoir de ceux étant près de la source, à la manière de la transmission par voie orale de la tradition.
Ce document est protégé par la loi sur le droit d'auteur. L’utilisation des services d'Érudit (y compris la reproduction) est assujettie à sa politique d'utilisation que vous pouvez consulter en ligne.

https://apropos.erudit.org/fr/usagers/politique-dutilisation/ 


\title{
Keeping Choro Alive in Brazilian Concert Music for Bassoon
}

\author{
Ariana Pedrosa
}

\begin{abstract}
Brazilian concert music for bassoon - the fruit of the Brazilian nationalist movement of the 19th and 20th centuries - is challenging for performers due to the circumstances in which this repertoire emerged and the influences underlying it. Here, the role of Brazilian popular music in the formation and establishment of this repertoire is often unstated or understated. One important popular genre unique to Brazil is choro. It is impossible to deliver a faithful performance of many of the Brazilian nationalist music pieces heavily influenced by choro without some acquaintance with this genre. These considerations have become especially relevant due to the widespread popularity of Brazilian concert music repertoire for bassoon all around the world. Informed performance practice in 'good taste' can result, among other, from closing the gaps in knowledge, providing sufficient and clear background and reference information, raising awareness for practices and conventions of the time and style, and passing on the insight of those close to the source in a manner of oral tradition.
\end{abstract}

Keywords: bassoon; Brazilian concert music; Brazilian nationalism; choro; performance practice.

\section{Résumé}

La musique de concert brésilienne pour le basson, fruit du mouvement nationaliste des $\mathrm{XIX}^{\mathrm{e}}$ et $\mathrm{XX}^{\mathrm{e}}$ siècles, apporte un défi aux interprètes étant donné les circonstances dans lesquelles ce répertoire émergea ainsi que les influences qui lui sont particulières. Ici, le rôle et l'influence que la musique populaire brésilienne a eu dans la formation de ce répertoire est souvent méconnu ou sous-estimé. Un genre important de la musique populaire brésilienne, unique à cette nation, est le choro. Il est impossible de proposer une interprétation fidèle, authentique, des nombreuses œuvres nationalistes brésiliennes, œuvres grandement influencées par le choro, sans avoir préalablement une certaine connaissance et un contact avec ce genre. Ces considérations deviennent particulièrement pertinentes en raison de la grande popularité dans le monde entier du répertoire de musique de concert brésilien pour le basson. La pratique de performance « de bon goût » peut, notamment, renforcer les lacunes dans les connaissance par le rapprochement des liens manquants, fournissant des informations et références de base suffisantes et claires, afin de sensibiliser aux pratiques et aux conventions de l'époque et du style, transmettant le savoir de ceux étant près de la source, à la manière de la transmission par voie orale de la tradition.

Mots clés : basson ; choro ; musique de concert brésilienne ; nationalisme brésilien ; pratique de performance. 
Music is a distinctive and powerful medium that allows people to communicate, convey messages and emotions, and transmit elements of their culture without the use of words (Miell, MacDonald and Hargreaves 2007). Listening to a piece of music from another era, geographic location or culture can provide the audience a great deal of insight into that time, place or culture. For this to happen, especially in the case of classical music, performers have to be able to decipher and interpret the composer's original intent as closely as possible. This process is not without its challenges, because not all elements of music can be embedded into a music score and, even if the composer records his or her intentions in the score as painstakingly as possible, the performer must still draw on extensive knowledge of the cultural, social, historical, and political circumstances, among others, that may have had a bearing on that composer's work.

Thus, interpretation and performance of 19th and 20th century Brazilian concert music today call for a certain degree of contextualization and revival. A product of multiple and changing elements, music develops and evolves at an extremely dynamic pace - and Brazilian music is no exception. Even within one's lifetime, one may see a musical style emerge into the spotlight and then fade into oblivion. Although the phenomenon of revival in music has existed for centuries in some shape or form (for example, Antiquarians; see Haines 2014), it increasingly gathered momentum in the 20th century. Along with the practice of music revival, the academic and scholarly study of its different aspects became more common and widely accepted. According to Hill and Bithell, the English-language literature on this topic is focused mostly on Western Europe and North America; however, this by no means reflects the absence of music revivals in other parts of the world (Hill and Bithell 2014, p. 9). Performers are often at the center of revivalist practice and driven by various motivations, ranging from dissatisfaction with the social or political status quo to promoting the identity of a certain group (ibid., p. 10-12). Whatever the performer's reasons for engaging in music revival, there are a number of challenges associated with its implementation. In The Pathetick Musician, Bruce Haynes and Geoffrey Burgess reflects on the relationship between past and present in music performance:

To the extent that the arts embody concepts of reality, they offer insight into how the world was perceived at the time they were made. And for that reason, if we are able to understand what the arts of the past have to say, they are very effective tools for studying human history. Many of our choices as musicians are made without great thought; they simply 'feel right'. And the results of those choices have produced the art we see, hear, and think about today. So to revive a historical artform, a knowledge of the assumptions and beliefs that were available in a given period is essential for making choices that do indeed 'feel right' for that period. This is not the only factor, to be sure. There are economic, educational, and social influences as well (Haynes and Burgess 2016, p. 5).

Although music by Brazilian composers such as Heitor Villa-Lobos (1887-1959) and Francisco Mignone (1897-1986) still seems relatively contemporary, its informed interpretation and performance requires a great deal of revival, i.e. understanding 
of the sociocultural, historical, political, and musical contexts in which it emerged. In addition, knowledge about and a feel for the musical styles that influenced Brazilian concert music is indispensable for recreating the original intentions of Brazilian concert music composers.

As the influences on the repertoire in question are too manifold and complex for the scope of one article, the focus here is on one Brazilian music genre that inspired many of the composers of that time: choro. Furthermore, this influence is examined specifically on the example of bassoon pieces, both in solo and chamber music. These works have now become a standard part of the bassoon repertoire and there is still a need to raise awareness among bassoonists for the considerations that are needed to inform their practice.

\section{Historical Context and Musical Background}

In the late 19th-early $20^{\text {th }}$ century in Brazil, riding the wave of Brazilian political nationalism after the country's independence in 1822, there was a clear desire on the part of concert music composers to create music that would be authentically Brazilian, represent a Brazilian identity, and be less influenced by a Western European musical esthetic. This was not unlike other movements in Europe and the Americas at the time; for example, The Mighty Five in 19th-century Russia collaborated to form a uniquely Russian musical style with distinct harmonic and melodic devices, making use of, among other things, the elements of Russian folk music (The Editors of Encyclopedia Britannica 2015). Similarly, in Brazil, to mold the nationalist music style, many composers relied on traditional Brazilian music for inspiration and raw material. Others, less intentionally, were simply influenced by the "street sounds" and the rhythmical and melodic elements of Brazilian popular music that could be heard on Brazil's streets and in bars and salons.

One highly prevalent popular musical style of that period was the choro, which is considered to be the first urban traditional music style in Brazil. Choro was instrumental in nature and required a high level of technical mastery along with improvisational skills. It emerged from the fusion of European ballroom dance music and lundu (an African music style), which occurred in the then Brazilian capital of Rio de Janeiro (Cazes 2010). Chorões (Figure 1), the performers of choro who usually came from lower or middle classes, joined together in small instrumental groups to perform polkas, waltzes, schottisches, quadrilles, and habaneras at different popular dances and festivities. 


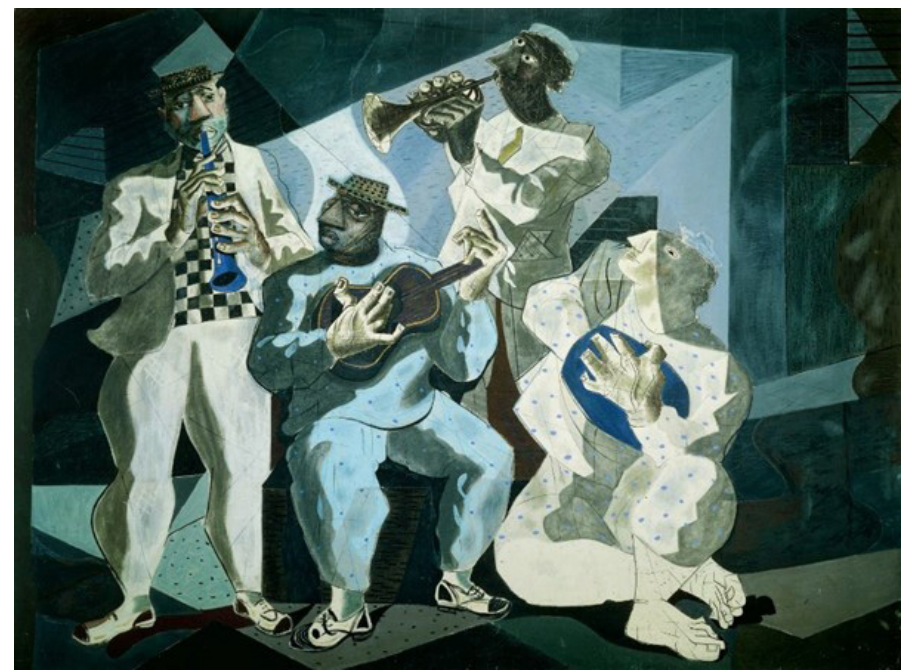

Figure 1: Chorinho by Candido Portinari, 1942 (C) Candido Portinari).

According to Henrique Cazes, as the capital city grew, "[a]n urban middle class emerged, comprising public officials and small business-keepers. This middle class, largely made up of Afro-Brazilians, did not only serve as the driving force of choro, but also as the audience that consumed this type of music" (Cazes 2010, pp. 15-16; my translation). These choro groups improvised on well-known themes from European salon music, which made its way across the Atlantic to Brazil's elite salons in Rio de Janeiro, and composed their own themes (ibid.). At the time, European salon music was being used as a foundation for the development of new distinct genres all over Latin and Central America (Brill 2018). Gerard Béhague, a prominent ethnomusicologist specialized in the music of Brazil, explained the transformation of European music in Brazil as follows:

European styles in fashion and other forms of popular music from abroad had always been present in the biggest cities, where some social classes had a tendency to emulate their European counterparts. For this reason, the main 19th-century ballroom dances, such as the waltz, mazurka, polka, schottische, contra-dance, and many others, were adopted with ease in all the cities, big and small, and over time, went through the process of 'creolization' or 'interbreeding', i.e., the process of transformation into local and national genres (Béhague 1992/1993, p. 2; my translation).

By the 1920s, when radio broadcasting spread all over Brazil, choro had consolidated itself as one genre, comprising various sub-genres. In the 20th century, many wellestablished Brazilian concert music composers such as Heitor Villa-Lobos, Francisco Mignone, Lorenzo Fernández (1897-1948) and Camargo Guarnieri (1907-1993) maintained a close contact with choro and chorões.

A distinctive feature of choro is the combination of instruments typically used in this music (Figure 2) and how these instruments were used. Flute was a common melodic instrument in the early days of this genre, while clarinet, saxophone and trombone were added later on. The cavaquinho, the seven-string guitar, and the mandolin were the typical string instruments played by the chorões, and pandeiro, a commonly used 
percussion instrument. Many of these instruments were originally brought to Brazil by the Portuguese, as pointed out by Vasconcelos:

With the Portuguese came all the basic musical instruments such as the flute, cavaquinho, the guitar - which, nearly four centuries later, would play a key role in the formation of choro and all of our instrumental music performed by small groups - as well as the piano, viola, ophicleide, clarinet, violin, double bass, cello, accordion, and pandeiro-[the latter] initially without the leather[,] that the Iberian peoples got to know when their lands were invaded successively by the Romans and the Arabs, also came to us from Portugal (Vasconcelos 1991, p. 20; my translation).

In the early days, it was also common for pioneers of the genre such as Chiquinha Gonzaga (1847-1935) and Ernesto Júlio de Nazareth (1863-1954) to perform and compose choro on the piano.
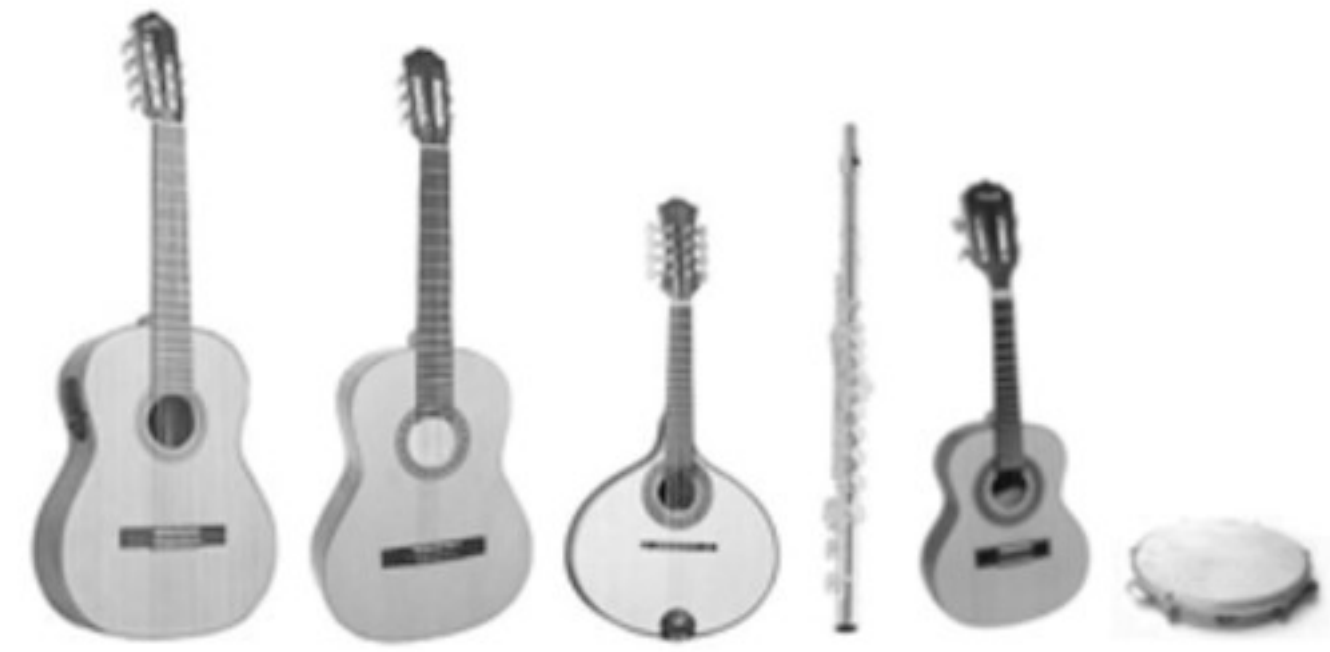

Figure 2: Traditional choro instruments (source: Panoramas Scholarly Platform).

Rich in rhythmical patterns, derived from European dances and modified to include syncopation and rhythmic anticipation, in the process of Euro-African syncretism widespread in Latin America (Orea 2015), choro melodies were characterized by profound expressivity, with the use of suspensions, appoggiaturas, ornamentation, and dissonance notes on strong beats. Another characteristic element of choro was improvisation in the form of melodic variation, whereby the melody remained discernible. Rather than free improvisation, it was idiomatic, resembling that of the practice of improvisation in Baroque music, "integrated into both the melodic and harmonic fabric of the music. To decorate, to supplement, to vary, to embellish, to improve, as it was often called, was an accepted part of being a performing musician" (Bailey 1992, p. 21). Choro ornamentation included glissandos, trills, flutter-tonguing, appoggiaturas in octave, and embellishments. The harmonic structure of choro pieces was tonal and European, with the use of triads and without many dissonances. It was also common practice to use chord inversions, instead of dissonant chords, creating active stepwise movement in the bass line, another of this genre's distinctive features. In addition, beat accentuation was closely tied to the note placement within the bar 
or meter. Melodies usually started on a weak beat of the bar, producing the effect of a shifted accent. Most importantly (but certainly not unique to this genre), although choro was notated by the choro composers, there was a great deal of discrepancy between what was written down in the score and how these pieces were performed in practice. Often, there were no indications of tempo, few or no articulation markings, and melodies written for one instrument in the score were played by various instruments in a lively interplay. For example, Flor Amorosa, a choro by Joaquim Callado, notated as just a melody with rhythmic indications (see Figure 3), is harmonized by a choro ensemble (see Video excerpt 1).

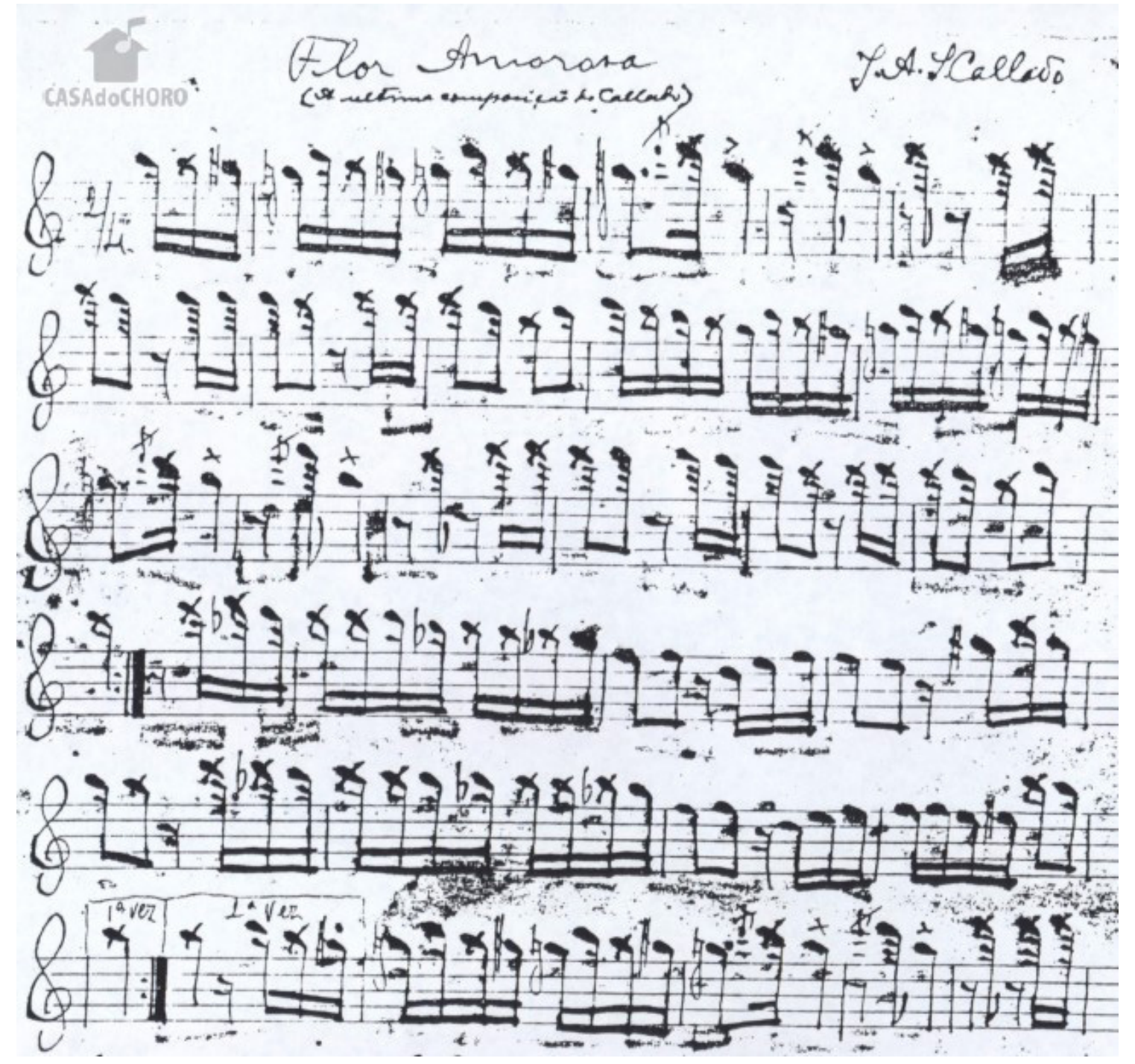

Figure 3: Flor Amorosa (1915) by J. A. Callado (source: Casa do Choro).

Video excerpt 1: Flor Amorosa performed by André Fajersztajn, Vanessa Ribeiro, Izaías Bueno, Camila Silva, Israel Bueno, Luizinho 7 Cordas, and Edinho Schmidt (source: Brasil Toca Choro, January, 2019). Watch the video.

This vibrant genre, along with several others, served as fertile ground for Brazilian nationalist composers, and examples of direct and indirect influences of choro on 
concert music are plentiful. Although the bassoon was not traditionally an instrument used by choro groups, concert music composers produced an unusual number of compositions for this instrument that was influenced, among other, by the choro genre. Works such as Bachianas Brasileiras No. 6 and Ciranda das Sete Notas by Villa-Lobos, 16 Valsas para Fagote Solo and Concertino by Mignone, and many others are now at the heart of bassoon repertoire and regularly performed in Brazil and around the world. Precisely due to this popularity, it is not uncommon to hear uninformed performances of these works, revealing a significant gap in contextual knowledge and perhaps a misunderstanding of what this music represents.

\section{DeVeloping Informed Practice}

Much has been written in the Baroque and Classical Eras about the importance of 'good taste' in music decisions of performers in these periods. This emphasis was largely due to the fact that, much like in the case of choro, music of that time called for a great deal of embellishment, ornamentation, and improvisation skills - oftentimes, a musical score was just an outline of the composer's intentions and the rest was left up to the performer and his (or, much less frequently, her!) 'good taste'. This idea is succinctly described by Nona Pyron as follows:

A thread which runs through many writings on music in the 17th and, particularly, the 18th centuries [...] is that of 'good taste.' In the $18^{\text {th }}$ century the highest accolade was often that a performer had played in 'good taste.' Good taste implied not only musicality, but a certain sense of discrimination - of knowing when, and when not, to apply certain conventions... and to what degree. Discrimination, by definition, implies that a choice is available-where there is no latitude for different kinds of behavior, there can be no question of 'good taste.' In the Baroque and Classical eras the conventions and implied practices provided a wide latitude of choices-and this, in turn, led to the great emphasis musicians and the musical public of that time placed on the question of 'good taste' (Pyron 2009, p. 1).

Needless to say, developing this ability to discriminate, to make choices and decisions becomes more difficult if the task at hand is performing music from a past era, a different sociocultural or political system, or a system of conventions and practices that the performer is unfamiliar with. Luckily, in the case of the Brazilian music under scrutiny here, we have easy access to interviews with musicians for whom these compositions were written, or who knew and had professional interactions with the composers (for example, bassoonist Noel Devos, as detailed below). There are also those who still maintain the practice of living in two worlds: that of concert music and that of choro (for example, clarinetist Paulo Sergio Santos of Quinteto Villa-Lobos, flutists Antonio Carasqueira and Nilton Moreira, guitarist Paulo Aragão, and pianist André Mehmari, just to name a few). Lastly, since choro is a practice still very much alive, there are many active choro clubs, schools, and festivals in Brazil and around the world. After disappearing from Brazilian musical life in the 1930s, the practice of choro itself underwent a revival in the 1970s (Livingston 1999, p. 67).

The French-born bassoonist Noel Devos (born 1929), who sadly passed away in early 2018, spent more than 60 years living and working in Brazil. An active musical 
figure in the bassoon world, he dedicated much of his time to promoting Brazilian music repertoire for the instrument. His personal interactions with Heitor Villa-Lobos and Francisco Mignone were vital for the formation of Brazilian bassoon repertoire. Bassoonist and researcher Ariane Petri believes that Devos has been instrumental to the development of the bassoon school in Brazil (Petri 1999).

I have had the privilege of both participating in a masterclass given by him on Villa-Lobos's Bachianas Brasileiras No. 6 in 2000 and interviewing him in 2015 and 2017 (Figure 4). The sixth Bachianas was composed in 1938 for flutist Alfredo Lage and bassoonist Evandro Pequeno, both amateur musicians, and it combines elements of inventions by J. S. Bach, such as voice exchange, inversion, and imitation, with the elements of choro, namely, a lamenting melody, big leaps, and the impression of an improvised discourse. Villa-Lobos himself commented on his choice of instrumentation for Bachianas Brasileiras No. 6:

I chose the combination of two instruments (flute and bassoon) to suggest the old Brazilian serenade for two instruments, and I substituted the ophicleide with the bassoon, because this instrument is nearer to the spirit of Bach and I wanted to give the impression of the improvisation as in serenade singing. This suite is more 'Bachian' in form than 'Brazilian'. (Palma and Chaves Jr. 1971, as cited in Fagerlande 2008, p. 106; my translation).

Although Devos's status certainly did not require any justification, in the masterclass he explained: "Now, I can tell you something about this music, but when I came to this country 40 years ago, I would not be able to help you. I had excellent technique, but I did not understand anything about Brazilian music, and it was Villa-Lobos himself who told me that! Today, I know what he meant perfectly!" (Devos 2000; my translation). At another point in the masterclass, he recounted having told Mignone that the articulation he wrote was too hard for the bassoon, to which Mignone responded: "Hmm, alright, just do it your way, I am sure it will turn out great!" (ibid.). It became clear to me in the course of this masterclass that this bassoonist was a treasure of first-hand knowledge, which drove me to return to interview him in 2015 and, again, in 2017.

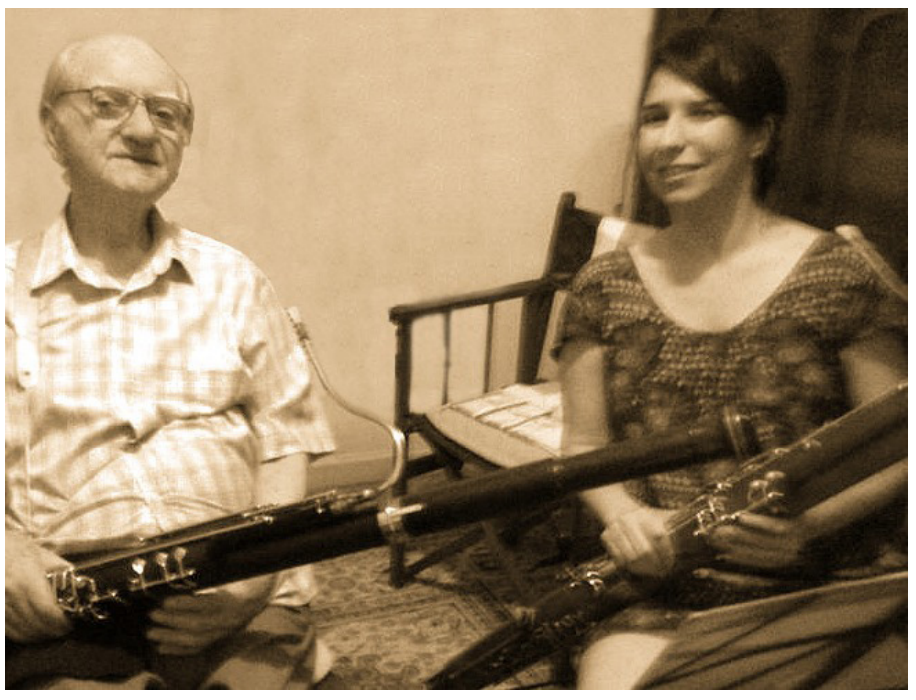

Figure 4: Photograph of Ariana Pedrosa with Noel Devos, 2017. 
In an extended interview with Lauro Gomes in September 2015, Devos recounted the advice Villa-Lobos gave him and flutist Odette Ernest Dias about performing the first movement of Bachianas Brasileiras No. 6. He describes a sort of duality of VillaLobos's intentions with respect to this composition: a performance that is wellprepared and accurate, yet free in the manner of a serenade (Video excerpt 2). This anecdote highlights one of the challenges faced by players in tackling this repertoire, as well as the importance of passing on the valuable insight held by performers such as Devos, continuing the oral tradition.

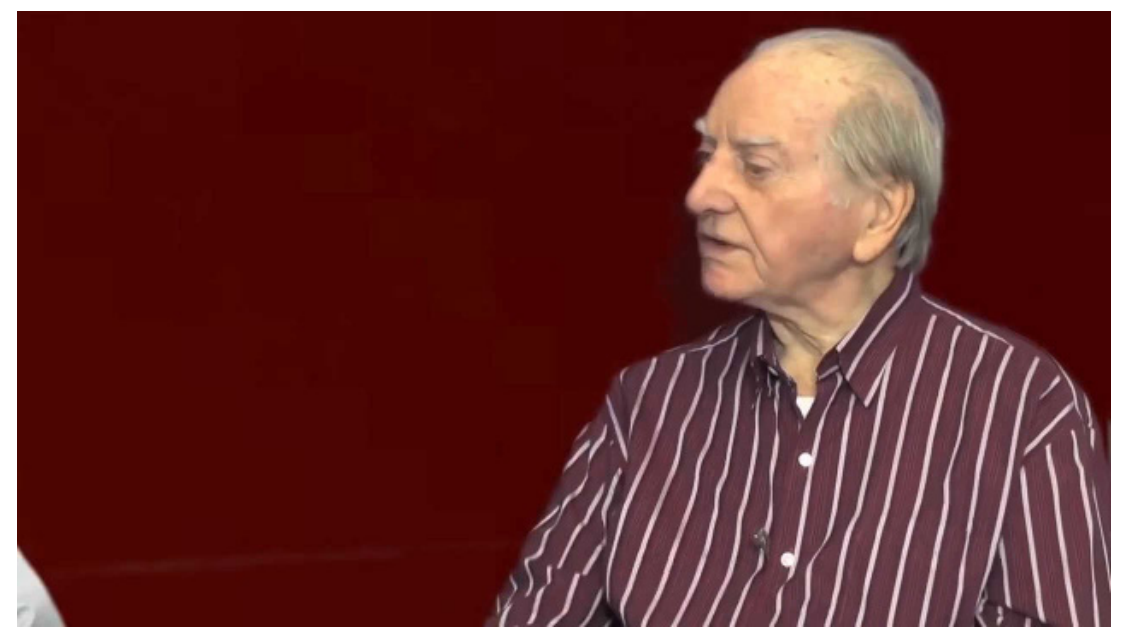

Video excerpt 2: Excerpt from Lauro Gomes's interview with Noel Devos, September 2015 (source: https: / www.youtube.com/watch? $v=3$ jWAZTA4BM, English subtitles added by the author).

A lesson with the Brazilian choro clarinetist Pedro Paes reflected another side of performance practice as an oral tradition-one that is not passed on through words. In response to my question about how to play a particular phrase from Villa-Lobos's Ciranda das Sete Notas with a choro touch, he simply picked up his clarinet and played the phrase for me, modifying the agogics and articulation. This was precisely what I had heard Villa-Lobos himself describe in his interview on the French radio (Video excerpt 3). Impressed by the result, I repeated the phrase after Mr. Paes, learning and adapting my interpretation of the piece through imitation. This is a good example of the strong role of aural transmission in interpretative practice (Medeiros 2015). Furthermore, it shows that chorões of today can shed light on various questions of interpretation of Brazilian nationalist music.

Video excerpt 3: Excerpt from an interview with Villa-Lobos in French, May 1958 (source: "Villa-Lobos explique en français ce qu'est un 'choro(s)'," Youtube video). Watch the video.

An important academic/educational format that I have been exploring in connection with this music is the lecture recital. This format is unique in that it allows for the presentation of research results, raising awareness among the academic and professional community, and nurturing 'good taste' - all in one sitting. In particular, in one such lecture recital held as part of the Doctor of Musical Arts studies at the Music Faculty of the Université de Montréal in April of 2018, I paired excerpts from concert music repertoire for bassoon with choro pieces - the fruit of my research project into 
performance practices of Brazilian bassoon music in the previous years. In addition, my choro group (with myself on bassoon) performed arrangements of European pieces in a choro manner to demonstrate how non-Brazilian music can be playfully turned into a choro. Georg Phillip Telemann's Sonata in F minor for bassoon seemed especially suited for this purpose, since Telemann himself was notably an avid experimenter with mixed-style compositions (Paoliello 2017). The entire performance was narrated with the aim of guiding the audience through this musical experience (e.g. pointing out what to listen for). This combination of research with hands-on practice seems ideal for passing on the oral tradition and contributing to the development of 'good taste' with respect to Brazilian nationalist music.

Lastly, as mentioned above, choro is a full-fledged and well-established style. Ensembles of chorões and choro clubs (clubes de choro) can now be found all over the world, from South and North America to Europe and even Australia. Choro festivals are increasingly taking place in major world cities such as New York and Paris. For those who are interested, opportunities to learn about this genre are often just 'one step away.' But even for those in more remote corners of the world and with fewer opportunities to experience choro live, countless sound examples are now available online. Some useful resources include Brasil Toca Choro, a Youtube channel of the Brazilian Cultura television network, and Jazz at Lincoln Center's Jazz Academy Youtube channel.

Thanks to the aforementioned tools, many of which are available to performers today, it is no longer indispensable to spend years living in Brazil in order to develop 'good taste' for Brazilian concert music and to be able to deliver a well-informed and faithful performance. Oftentimes, not realizing the shortcomings of their interpretation or not knowing where to look for reliable and helpful information is what prevents performers from seeking knowledge and expanding their horizons with respect to a particular style of music. Therefore, my aim is to use field research in combination with performance to raise awareness for the inner workings of Brazilian nationalist music, provide performers with background information, point them to useful sources, and equip them with the tools that could be helpful in mastering this music - in short, to facilitate their job of transposing audiences to the world of Brazilian concert music.

\section{BIBLIOGRAPHY}

Bailey, Derek (1992), Improvisation. Its Nature and Practice in Music, London, British Library National Sound Archive.

Béhague, Gerard (1992/1993), "Recursos para o Estudo da Música Popular Latino Americana," Revista Brasileira de Música, Rio de Janeiro, vol. 20, p. 2.

Brasil Toca Choro Januery (2019), "Flor Amorosa/Joaquim Antônio da Silva Callado," https://www.youtube.com/watch?v=nymVeYdlY4k, accessed 23 February 2019.

Brill, Mark (2018), Music of Latin America and the Caribbean, New York/London, Routledge/Taylor \& Francis Group.

Callado, Joaquim (1915), Flor Amorosa, hand-written score, http://acervo.casadochoro.com.br/files/ uploads/scores/score 866.pdf, accessed 23 February 2019. 
Cazes, Henrique (2010), Choro. Do quintal ao Municipal, 4th edition, São Paulo, Editora 34.

Devos, Noel (2000), Masterclass held in November 2000, Rio de Janeiro.

Devos, Noel (2015, 2017), Interviews conducted by Ariana Pedrosa at Mr.Devos's home in Rio de Janeiro on November 30, 2015 and March 17, 2017, oral recording.

Devos, Noel (2015), Entrevista com Noel Devos, Brasil Classico - Lauro Gomes Entrevista, https://www.youtube.com/watch?v=3 jWAZTA4BM, accessed 3 April 2019.

Fagerlande, Aloysio (2008), O Fagote na Música de Câmara para Sopros de Heitor Villa-Lobos, Ph.D. diss., Universidade Federal do Estado do Rio de Janeiro.

Haines, John (2014), "Antiquarian Nostalgia and the Institutionalization of Early Music," The Oxford Handbook of Music Revival, New York, Oxford University Press, http://www.oxfordhandbooks. com/view/10.1093/oxfordhb/9780199765034.001.0001/oxfordhb-9780199765034-e-011, accessed 5 April 2019.

Haynes, Bruce, and Geoffrey Burgess (2016), The Pathetick Musician. Moving an Audience in the Age of Eloquence, New York, Oxford University Press.

Hill, Juniper, and Caroline Bithell (2014), "An Introduction to Music Revival as Concept, Cultural Process, and Medium of Change," in Juniper Hill and Caroline Bithell (ed.), The Oxford Handbook of Music Revival, New York, Oxford University Press, http://www.oxfordhandbooks.com/ view/10.1093/oxfordhb/9780199765034.001.0001/oxfordhb-9780199765034-e-019, accessed 5 April 2019.

Livingston, Tamara Elena, and Thomas George Caracas Garcia (1999), "Music Revivals. Towards a General Theory," Ethnomusicology, vol. 43, n 1, pp. 66-85.

Miell, Dorothy, Raymond MacDonald and David J. Hargreaves (2007), Musical Communication. New York/Oxford, Oxford University Press.

Medeiros, Elione Alves de (2015), "Transmissão aural e edição : As 16 Valsas para fagote solo Francisco Mignone," Ph. D. diss., UNIRIO.

Orea, Rene (2015), "Le rythme dans les musiques traditionnelles de l'Amérique du Sud Modélisation, typologie et signification culturelle," Ph.D. diss., Université de Montréal.

Paoliello, Noara (2017), "Gosto, Gênero e estilo em Telemann," IV Simpósio Acadêmico de Flauta doce da EMBAP, Paraná, Anais do Simpósio de Flauta Doce, EMBAP, pp. 3-16.

Petri, Ariane (1999), "Obras de compositores brasileiros para fagote solo", M.A. diss., Universidade Federal do Rio de Janeiro.

Pyron, Nona (2009), "Aspects of 17th and 18th Century Performance Practices. The Question of 'Good Taste' and Implied Rhythms," Grancino Editions, https://www.grancinoeditions.com/ resources.html, accessed 2 December 2018.

The Editors of Encyclopaedia Britannica, "The Mighty Five," Encyclopaedia Britannica, https://www.britannica.com/topic/The-Five, accessed 5 April, 2019.

Vasconcelos, Ary (1991), Raizes da música popular brasileira, Rio de Janeiro, Rio Fundo Editora.

"Villa-Lobos explique en français ce qu'est un 'choro(s)'," https://www.youtube.com/ watch?v=aAijyeE10A4, accessed 1 December 2018. 